\title{
GLOBALISATION, CULTURAL DIVERSITY AND LUSOPHONY: TRANS-SPATIAL CIRCULATION OF PORTUGUESE SPEECH AND ITS RELATIONSHIP WITH OTHER SPEECHES
}

\author{
Armando Jorge Lopes
}

\begin{abstract}
I shall discuss several questions involving the concepts of globalisation, cultural diversity and Lusophony in a transdisciplinary fashion, resorting to the notions of crossings and passages, mediated by Applied Linguistics and supported by Language Planning and Language Policy. The crossing, wrapped in novelty and perilousness, speaks of oceans, affording us complex challenges and, at times, frightening us. The passage seems to be more controlled, and associated with less enigmatic and more secure experiences, perhaps because both banks of a river can usually be seen from any point as we pass through it. In a river, we travel across from one bank to the other. And in the ocean, what happens? Lusophony and its contextualisation, in my opinion, is the crossing, viewed from a transdisciplinary perspective and through applied linguistics, including cultural diversity in a world claimed as global. Through Language Planning and Language Policy, both established as useful tools for a possible outline of some futuristic notion, Lusophony is here understood as passage. The focus of the present article falls therefore upon the concept of Lusophony as a place of reflection, of knowledge as well as recognition of oneself and the Other. This concept of Lusophony is instantiated by the notion of relation vis-à-vis globalisation and by the essence here portrayed by the linguistic ecological system of Portuguese.
\end{abstract}

\section{GLOBALIZAÇÃo, DiVERSIDAdE CULTURAL E LUSOFONIAS: CIRCULAÇÃO TRANS-ESPACIAL DA FALA PORTUGUESA E SUA RELAÇÃO COM OUTRAS FALAS}

\begin{abstract}
RESUMO
Discuto transdisciplinarmente questões várias que envolvem os conceitos de globalização, diversidade cultural e lusofonia, recorrendo a travessias e a passagens mediadas pela Linguística Aplicada e suportadas pela Planificação Linguística e pela Política Linguística. A travessia, envolta em novidade e perigosidade, fala-nos de oceanos, proporcionando-nos desafios complexos, e colocando-nos, por vezes, em sobressalto. A passagem parece ser mais controlada, associada a experiências com menos enigmas e mais seguras, talvez porque habitualmente se avistam as margens de um lado e do outro, a partir de diferentes pontos do rio, quando efectuamos a passagem. No rio passa-se de uma margem para a outra. E no oceano, o que acontece? Numa perspectiva transdisciplinar e através da linguística aplicada, a lusofonia e a sua contextualização, incluindo a diversidade cultural num mundo pretendido global é, por mim entendida, como sendo a travessia. Através da Planificação Linguística e da Política Linguística, que se constituem em instrumento útil para um esboço possível de uma noção virada para o futuro, a lusofonia é aqui entendida como uma passagem. O enfoque do presente artigo recai, pois, sobre o conceito de lusofonia como lugar de reflexão, de conhecimento e de reconhecimento de si e do Outro,
\end{abstract}


conceito este instanciado pela noção da relação vis-a-vis Globalização e pela essência aqui representada pelo sistema ecológico linguístico do Português.

Patavras-chave

Lusofonia; globalização; relação; Planificação e Política Linguística; Linguística Aplicada

\section{MY RESEARCH POSITION ON GLOBALISATION, CULTURAL DIVERSITY AND LUSOPHONY ${ }^{1}$}

The approach to reality cannot merge methodological opposites, as for example, amongst others, experimentation, governed by rigid procedures, and histories, which are reconstructed subjectively. Therefore, it reinforces the idea of multi-party action, an action through which we can, for example, explain one phenomenon or event as a physical entity, and another, by which we try to understand the event as symbolic motifs. But such a pluralist approach requires mental adjustments from researchers, because, since experimental research and ethnographic research are so different, it is difficult to think or work in various directions at once. What is possible, through careful shifts in velocity, is to alternate between the different approaches, developing a creative tension between alternative points of view. As much as to realize experiences as to make histories, researchers need guidance as to which topics need to be explained and which topics need to be interpreted. In linguistics there is, for example, a certain concordance in separating the process of language acquisition from that of its use, and this division merely serves to underline our points of view, that is, we view language as an object or we see it a complex of symbolic motifs. The human and social sciences, when compared with the natural, technical and exact sciences, were and still are considered as distant cousins in the nomothetic tradition. This tenuous relationship has to do with the status of the social sciences themselves, in which only experimental psychology is considered, in this tradition, as the most nomothetic social science. Plato's view, so rooted in the natural and exact sciences, remains the point of purely formal theory, constituting the central preoccupation of generative transformational linguists. There are, however, recent developments in the social sciences in search of a paradigm which better receives the hermeneutic dimension and establishes a more satisfactory balance between the hermeneutic and nomothetic dimensions, such as that being attempted in applied linguistics, ethnomethodology, educational ethnography, psychological and sociological humanism, refining and perfecting our sensibilities in order for us to avoid the risk of making meaningless interpretations.

The traditional research posture, and the process of teaching and learning, is disciplinary because, in the approach to and analysis of a question, it privileges a focus which is circumscribed by the parameters and limits of a discipline or field in order to understand it: for example, it attempts to understand a discourse infelicity through simple recourse

\footnotetext{
'Research developed in the context of the project "Memories, cultures and identities: how the past weights on the presentday intercultural relations in Mozambique and Portugal?", supported by Aga Khan Development Network and Portuguese Foundation for Science and Technology.
} 
to the discipline of Text Analysis. Latterly, the so-called interdisciplinary posture came to be associated with and blended, in its approach and analysis, with knowledge and skills from other disciplines apart from Text Analysis, such as for example the disciplines of Discourse Analysis, Behavioural Psychology and Cognitive Psychology in order to try to understand the question of discourse infelicity in the communication of speakers and writers.

The transdisciplinary posture to research, and the teaching and learning process, operates on the basis of the belief that there exist knowledge, concepts, skills, attitudes and actions which transcend the frontiers of a single disciplinary field and which forge the curriculum in a coherent transdisciplinary whole which is involving, relevant and meaningful. Adopting a transdisciplinary posture means that people from two or more disciplines teach, learn and work jointly across disciplinary boundaries or traditional professions. It is clear that a transdisciplinary posture is supported by interdisciplinary approaches which combine or involve two or more disciplines or fields of study, and it is sometimes fed by intradisciplinary postures in which the focus rests at the heart of the same discipline or with people who are actively working in it.

On the other hand, multidisciplinarity, which involves multiple academic disciplines seeking to resolve problems beyond the usual boundaries, reveals parallel disciplinary reflections, placed side by side for consideration, differently from transdisciplinarity, which is more integrative, and socially more inclusive. Transculturality, a posture which searches for shared interests and common values, is based on breaking boundaries, being markedly different from multiculturalism because this latter posture tends to reinforce boundaries based on past cultural inheritance: the multicultural posture relates one culture with another, or other different cultures, while the transcultural posture expands itself across two or more cultures. Within the multicultural posture, where people live side by side, one with another, a particular cultural group does not necessarily, nor always, involve itself in interactions with other cultural groups. In the transdisciplinary posture, the knowledge generated in its application is never reduced to any single discipline that competed in its generation, and no distinction is made between basic or pure knowledge and applied knowledge, nor between theoretical or basic research and applied research, because the relationship between these types of knowledge and investigative idealizations does not occur in only one way. As I have argued (Lopes, 1998, p. ix) in relation to the customary distinction between theoretical and applied research, and including even practical investigation (this third category, related to didactics, is often ignored or discounted), namely:

from constructing models to explain a given phenomenon, to investigating the applications of theoretical constructs in discipline $x$ to a given context, to the practical utilisation of theoretical and applied findings in teaching methodology and classroom learning, each category of research should ideally contribute to revision of the content and structure of the other categories.

Put perhaps in the simplest way: theoretical research informs the applied and this, in turn, the theory or in the case, for example, of the preparation and didactic elaboration 
of manuals, applied research (or even theoretical research of a direct type) informs the practical research and this, in turn, informs the theoretical or applied research. Applied research naturally also has its theoretical foundations, the transdisciplinary posture being simultaneously theoretical and applied and driven by specific socio-economic and cultural necessities, through the adoption of multiple research methodologies aimed at creating solutions responding to the demands of society, and transforming social practices needing change or innovation.

Transdisciplinarity, a term created by Jean Piaget in 1970, aims to stimulate new understandings of reality through the articulation of elements which cross disciplines, passing them among themselves, and from elements which go beyond the disciplines, promoting the greatest interaction possible between them, respecting all the while their individualities, in which each one collaborates for a common knowledge without being transformed into a single discipline. In the present case of studies on culture and language, transdisciplinarity aims equally to de-naturalize questions of cultural and linguistic hegemony, the root trans- of the term being the bearer of a sense of multidirectional and reciprocal movement (never in one direction only), of mutual support through experience and of fair exchange, as in my opinion, the terms transculturality and translingualism also suggest.

In order to conceptually reinforce the aspect of reciprocity within the scope of transdisciplinarity, translingualism and transculturality, I turned to research at the heart of behavioural psychology and, especially, Osgood's (1949) paradigms of transfer, in the dimensions of proaction and retroaction. Proaction is an action which anticipates a future situation, not occurring simply as reaction. It describes the possible control and power to make certain things happen and not simply to adjust things to a given situation, or waiting for something to happen. Retroaction is a reciprocal action, describing an event, stimulus or process having an effect on the effects of previously occurring events, stimuli or processes.

Through proaction are visible the effects on a determined task 2, and following the execution of a task 1 ; on the other hand, through retroaction are visible the effects of task 2 on task 1, as happened in the past and continues to happen, for example in relation to linguistic and cultural transfers from Portuguese to Bantu languages, reciprocally enriching and complementing the linguistic and cultural transfers of the Mozambican Bantu languages which, to a considerable degree, have fed Mozambican-Portuguese throughout many decades.

In relation to the discipline of Applied Linguistics $(A L)$, the transdisciplinary posture falls, in my opinion, on the convergence between scientific and indigenized theory, which is practice, as James (1993, pp. 17-32) called it. Thus, for example, the transdisciplinary posture falls relevantly in many spaces and approaches between linguistic theory and the theory of language teaching, which is an AL pioneer area (related to the methodologies of teaching-learning process), feeding both theories, in a reciprocal fashion, as proaction and retroaction - or as unity in diversity: Mozambique in the CPLP (Community of Portuguese-Speaking Countries) and the CPLP in Mozambique. 
It is clear that in such a dynamic, the AL discipline, in its theoretical and indigenized dimensions, needs to renew itself, and through it, general linguistics itself, which is fundamental to it, would also need to renew itself. In this respect what Rajagopalan (2003, pp. 79-80) says is appropriate:

what applied linguistics needs to do urgently is to rethink its own raison d'être as a discipline, and to find its own academic credentials, admitting even, as one of the possibilities at the end of this path, that the new discipline may be an alternative to the mother discipline (i.e., general linguistics).

And following on, he concludes thus: "put another way, the task of reanimating the mother discipline itself... which is in a sickly state, and in need of a new spirit, might be reserved for applied linguistics".

As for transculturality, and following Mary Louise Pratt in Sanches (2005, p. 240), with whom I am essentially in agreement, the term is based on the concept created in 1940 by the Cuban Fernando Ortiz, in the light of his socio-anthropological thinking (1940/1963): "although subordinated peoples generally do not control what emanates from the dominant culture, they determine, to a certain point, what is absorbed by their own culture and what it is used for".

It is as if you were dealing with a process in which someone always gives something in exchange for what they receive, it is how one individual sees himself in the other - a process in which the two parts of the equation emerge changed. The transcultural posture (Lopes, 2017) has to do with the capacity to connect with people of different languages and cultures, and to place these languages and cultures in conjunction and reciprocity in order to improve the livelihoods of each and all: the capacity that ensures that we learn to acquire the knowledge and skills necessary to function in our own culture - intraculturality - and function in the culture of other individuals - interculturality which, sometimes, has to do with the relationship between cultural majorities and cultural minorities. Intraculturality and interculturality are component-postures of transculturality - which emphasizes integration through exchange and interaction, the production of knowledge and its dissemination being contextualized, and multiple and varied social actors involving themselves in it, in a broad and participatory way.

\section{Globalization, RELATION AND LUSOPHONY}

A little more than a decade ago, Lopes (2004, pp. 218-222) discussed the question of linguistic universals and their relation to the so-called 'de-babelization' of humanity. I return to the subject, including its historical contextualization. In 1951, a French commission set up by Unesco, which included Gougenheim, began developing a project - a simplified form of French for international use - which was initially called "Basic French", later "Elementary French", and finally "Fundamental French". The vocabulary was considered diminutive, but the main criticism of the simplified language project was that it was judged to impede the spiritual and intellectual development of the broad masses 
of people, especially on the African continent. Thus, widely criticized, the initial objectives of "Fundamental French" as a language of diffusion and potentially as a universal language, as intended, ended up being limited to the much more modest objective of a methodological programme for language teaching.

On the other hand, a more famous attempt which had the greatest impact was undoubtedly "Basic English", a programme launched with the ambitious intention of solving the problem of multilingualism, as their mentors said. Thus, neither the French research attempt nor the English one succeeded in concretizing the "de-babeling" of mankind, leaving behind far more modest results, such as 'providing teaching methods to language teachers'. As major languages of wider communication, neither French nor English were able to resolve at the time the desire to realize a single universal language, after previous unsuccessful attempts to introduce and use artificial languages as universal languages.

And in Mozambique what happened in relation to Fundamental Portuguese? At the time of National Independence, a project called "Fundamental Portuguese" was developed at the then Department of Modern Letters in the Faculty of Letters at Eduardo Mondlane University in Maputo, which, among other objectives, aimed to build a vocabulary matrix of 2000 elements. In my opinion, "Fundamental Portuguese" shared many of the traits characterizing the methodological approach of precursory experiences, in particular, the French one. Reacting against the behaviourist ideas guiding American philosophy and psychology in the 1950s, Noam Chomsky argued that each and every child learned to speak and understand a language through a certain structured and innate capacity for that purpose. For Chomsky, the congenital talent for speech and comprehension showed that verbal consciousness rests on an invisible framework of abstract universals that are limited in number, and that is what causes the generation of an unlimited number of possible transformations in a given language; that every human language depends on a transformational generative grammar and that the emphasis lies on the intrinsic properties shared by each language. In fact, modern general linguistics rests, to a considerable degree, on the principles of generative grammar, as originally defined by Chomsky over half a century ago. And thanks to Chomsky's work on the nature of language, we can now better understand some aspects of the structure of human communication: his later adopted mental model is explicitly computational, assuming the existence of predetermined patterns that guide each sentence that humans speak.

But at the same time, was the deliberate and incessant quest for linguistic universals not situated in the same logic as the attempts at de-babeling? Could it be that the more the problem of universality is emphasized, the less the shadows we have about the knowledge and functioning of language? In the context of literature, I recall, by analogy, the passage of a text by José Craveirinha (1954), "Race Consciousness", published in the weekly journal Brado Africano (6/11/1954), when referring to what he considered to be the absence of a literary culture of African expression in Mozambique and what he felt it was necessary to do: "not to abdicate an indigenous culture, nor to deny a European current, when from such a graft can come about an integral improvement in the richness of expressive rhythm in a literary form". And he went on to say, "from this principle came the 
cry of the poet Senghor of Senegal: 'Why not unite our two clarities in order to suppress all the shadows?"'.

We know that the processes of homogenization always seem to generate other new processes of homogenization in their midst, as happened with the fragmentation of Latin in the Romance languages. But many transformations take place silently, once power in these new times no longer seeks to confront diversity. Now, it tries, however, to control it, as Mosquera says (2001, p. 32):

it is obvious that globalization does not consist of an effective interconnection of the entire planet by means of an articulated grid of communications and exchanges. Globalization is rather a radial system that extends from several centers of power with a varied dimension to multiple highly diversified economic zones. Such a structure implies the existence of vast zones of silence, practically disconnected with each other or only indirectly linked through the metropolises... Globalization has undoubtedly improved communication at an extraordinary level, stimulated and pluralized cultural circulation and created a more pluralistic consciousness. However, it did so through the same channels followed by the economy, reproducing in this way, to a large extent, the structures of power.

At the recent colloquium (10/5/2017) at the Polytechnic University of Maputo, focussing on research, dissemination of knowledge and cultural production, Moisés Martins highlighted the relation between things, languages, cultures and individuals from all quarters as fundamental in today's competitive world, where everything has economic and financial value, including people, souls and spirits. In Martins's chapter, entitled "Portuguese language, globalization and Lusophony" (2014), he had already used the term relation when he emphasized Macedo's point of view, developed in her doctoral thesis:

this project raises the question of the diversity of the Portuguese-speaking world, putting the question that had already confronted the Portuguese maritime expansion: that of a noetic discovery, also of a philosophy of integration, and even that of an ideology of domination, as connections of the relation [emphasis mine] with the diverse world. (Martins, 2017, p. 28)

I consider the word and content of the term relation to be important, and I consider relevant reflections on the term in the context of the discussion of universals. My point of view is that the notion of relation is made up of all the differences around us and in the world, and that no difference should be overlooked however small it may be or may appear to be. If we adopt relation as an approach, what are we actually doing? What we do is to gradually move away from the idea of the universal and, ultimately, the idea of globalization, including the so-called "cosmopolitan globalization" and "multiculturalist globalization", even if it arises linked with multiculturalism (Martins, 2014, p. 24). In order to deal with interconnectivity and interdependence, the notion of relation seems to me more useful than the notion of globalization or that of universals. 
The universal in linguistics, or in any other social or human science, is an abstraction, and as such can guide us only to what is considered principal by making us forget the small difference. But relation, which is total, does not allow us to do this because relation is never made up of great differences. In this regard, Édouard Glissant, in conversation with the Malian Manthia Diawara, aboard the cruise liner Queen Mary II, sailing from Southampton to New York in August 2009, discussed this central notion in his reflections on culture and crossings in the world (or better, passages, a broader term that includes the oceans, thus not requiring shores to be in view):

why do I really need to understand the Other in order to live close to him and work with him? This is one of the laws of the Relation. In Relation, the elements do not mix in any way, they are not lost in any way. Each element can maintain its autonomy, its quality, even when one is accustomed to the essential qualities and differences of others. Each diaspora is the passage from unity to multiplicity. The only universality today is the universality of relationships based on diversity rather than unity. Multiplicity in totality is totally diversity ... There is no absolute truth, but instead truths. Everything is alive; everything is a Relation of differences, not of contraries, but of differences. Consequently, dialectics is not a linear approach toward what is contrary. Dialectic is a total rhizome of what is different... (Diawara, quoted in Barson \& Gorschlüter, 2010, p. 63)

And having found this relationship between the dialectic and the rhizome interesting, at the end of the quotation, what came to mind were various images of the largest cashew tree in the world, equivalent to seventy cashew trees of normal size, that I had the privilege of visiting at Pirangi, a few kilometers south of the city of Natal in northeastern Brazil. Instead of growing upwards, the tree's branches grew, and still grow sideways, bowing to the ground, due to their weight, at the same time as they are creating new roots for this giant cashew tree that covers about eight thousand square meters and has a circumference of five hundred meters. The type of aerial stem (in this case) grows horizontally close to the ground, an authentic rhizome in botanical terms, which concept was used epistemologically in Deleuze and Guattari's (1980/2004) philosophical theory with the sense of capturing multiplicities, contrarily to the concept of arborescent knowledge, with vertical connections. As a model for culture and the arts, the rhizome presents itself as a pole of attractions and influences, without concern for the beginning or end of things, always being in the midst of chains and organizations of power, including social, scientific and artistic struggles and challenges.

\section{LUSOPHONY, LANGUAGE POLICY AND LANGUAGE PLANNING}

In the structured chapter of Martins (2014, p. 25), the reference made to the ecological linguistic system is relevant, which, in addition to the Mozambican experience, is based on hybrid and non-hybrid experiences in the world. These are eminently social and linguistic experiences, inseparable from their environment, in which languages and 
cultural practices multiply, intersect and influence one another, generating hybrids in most situations.

Approximately two hundred and sixty million speakers in the world have made, and continue to make, Portuguese into a pluricentric and dynamic language, creating pressures that operate in all directions within the broad linguistic ecological system of Portuguese. The Portuguese language in Mozambique is necessarily part (and not an isolated part) of this complex system, which is amplified through Portugal, Brazil and the six African and Asian states (East Timor) that have Portuguese as their official language, which is amplified through communities and regions such as Macao, Goa, Daman and Diu, and strips along the straits of Malacca, as well as through so-called diasporic communities (around seven million speakers), in a significant number in non-lusophone countries, such as the Republic of South Africa, the United States of America, Belgium and France, among others. I argue that understanding the ecological linguistic system of Portuguese is indispensable for what can be better defined as Lusophony. Just as ecology shows that biological survival is essentially possible through a variety of forms, so too do I see the linguistic-cultural and civilizational survival of the different nations and peoples on earth.

In a wide and imagined space under construction, that starts with the Portuguese language and with multiple and varied historical ties as a common base, and in the perspective of a translingual and transcultural approach to the concept, the Lusophony, which I understand is developing as a way of being and becoming, seeks the shared spiritual, social and economic enrichment of the peoples and societies that are an integral part of it.

In a certain way, the peculiarity and idiosyncrasy of this tentative formulation were established, in particular, from the point of view of Lusophony in Ndhaneta (Lopes, 2012) and following the comment made by Martins in respect to it (2012, s.p.), namely:

I find this view on Lusophony very interesting. It begins with the current reality of the multicultural societies that impose on us - societies of mixed ethnicities, of the West and the East, the North and the South. It does not to forget history - a history of violence - since the history of the maritime and territorial expansion of western peoples to the east imposed colonization of the East by the West. It then moves on to what is fundamental: the importance of local languages and cultures, in the name of respect for diversity and the other, in the current process of worldization of economies, where the languages and cultures of the former colonizing peoples maintain their hegemony. Unless it is no more than a symbolic neo-colonialism, Lusophony cannot then be luso-centred - that would (will) be its biggest mistake.

And I second this position, agreeing with a more recent extract of the same author (Martins, 2014, p. 25):

Lusophony, instead of the impoverishing one-way homogenization established by cosmopolitan globalization, has the virtue of heterogeneity; the seduction of a net woven of yarns of various colours and textures, a net capable of resisting the reduction of the diverse to an artificial unit. 
Several conferences on Applied Linguistics $(A L)$ and others on the internationalization of the Portuguese language, including the "Lisbon Plan of Action", adopted at the 1oth Conference of the CPLP in Dili in 2014, have already been held for this purpose. In my view, further efforts are needed to articulate the important dimensions of linguistic policy and linguistic planning in dealing with the many issues surrounding Lusophony, including the fact that, when projected as an international language, the Portuguese language has, through it, the potential to help promote, in all senses, the nations and communities that speak Portuguese as their mother tongue, second language, foreign language and/or language in the diaspora. I argued some time ago (Lopes, 2015, pp. 197-200) and continue to think that, for the benefit of addressing multiple social, cultural and historical issues within linguistics, AL could be conceived and operated as a frontier interface, occupying the no-man's land between Language Planning, which is scientific theory, and Language Policy, which is the indigenized theory, that is, the theory of practice.

Language planning, formerly known as "language engineering", contributes through a set of activities aimed at making linguistic changes in a given community, and whose aim, at the level of the competent authorities, is based on the preservation of cultural identity, the maintenance of civil order, and the improvement of communication (Lopes, 2002, pp. 18-22; 1999, pp. 104-125). Language planning maintains close links with the field of social linguistics, which studies the social forces that influence linguistic change and the types of change motivated by these forces, as Kaplan and Baldauf (1997, p. 307) appropriately say, arguing that Language Planning is probably the supreme form of Applied Linguistics, and being understood as the treatment of the language as an eminently social phenomenon, as much in the plan of the corpus, as in the plan of the status:

we would want to argue that Language Planning is the ultimate form of Applied Linguistics; ... some of the notions available in grammatical theory are central to corpus work. But status work requires a quite different approach to the definition of language and to the understanding of the interrelationship between human populations and the language(s) they use in communicating with each other.

Language planning should specify the objectives which the policy aims to achieve and state the policy proposals. While recognizing the importance of space for utopias, any policy formulation that does not indicate its operationalization could prove useless. The fact that it cannot be implemented could indicate that the policies were based on an incomplete or insufficiently rigorous analysis of the situation to be overcome.

The problem to solve seems to be how to gather all the resources that are specifically needed for the relevant different target groups and how to satisfy the language needs of these same groups. Thus, based on the present and dynamic nature of these target groups, the policy should describe the traits of each group that are relevant to the identification of current and future language needs, and identify the steps to be taken for their satisfaction.

It is argued that the thoughtful elaboration of language policy as well as proper planning of its management are fundamental elements in order to maximize the familiarity 
and awareness of the target groups in relation to Portuguese, and also to maximize its potential for use in official, commercial, technical and cultural cooperation within the scope of Lusophony. Below is a preliminary outline of a three-phase programme of work, with a view to articulating language planning and policy in the field of Lusophony, within a transdisciplinary perspective, using applied linguistics.

\section{PHASE OF THE IDENTIFICATION AND DESCRIPTION OF THE HISTORIC-LINGUISTIC-CULTURAL NATURE OF COUNTRIES/ SOCIETIES}

The starting point in delineating a Portuguese language policy is to identify and describe, essentially, the historic-linguistic-cultural nature of the countries and societies that the policy aims to serve (Lopes, 2013b, pp. 30-33), with particular focus on the following elements, amongst others:

\section{A. LINGUISTIC AND CULTURAL DIVERSITY}

1. Level of "high linguistic diversity" of each country, which is important at the outset to best fit the strategies of diffusion, study and development of Portuguese

In this context, the definition proposed by Robinson (1993, p. 54) for the concept of "high linguistic diversity" is useful, namely: "a situation where no more than $50 \%$ of the population speak the same language"; further adding that: "a ranking of degree of linguistic diversity should not be based on the absolute number of languages in a country, but rather on the percentage of the population speaking any single language".

2. Level of plurilingual and pluricultural composition of target groups

For example, for Mozambique and Angola, members of the SADC (Southern African Development Community), and Equatorial Guinea, member of the CPLP (as are Mozambique and Angola), what is the situation of these countries and others who have Portuguese, English or French as official European languages? To properly understand their plurilingual and pluricultural geography is important for the design of negotiation strategies for a greater diffusion and promotion of Portuguese in plurilingual and pluricultural contexts.

\section{B. ECONOMIC AND BUSINESS DEPENDENCY AND INTEGRATION}

3. Level of economic dependence on internal and external trade by each country/ society, as well as the level of their economic integration in the context of the rest of the world

After identifying and describing the historic-linguistic-cultural nature of countries/societies, the following steps are suggested:

a) state the respective psychological, economic, political and cultural needs at the level of countries/ societies and persons;

b) formulate objectives and goals in this context; 
c) make policy proposals, setting priorities for countries, societies and target groups to be covered;

d) elaborate recommendations regarding the implementation of the policy; and

e) set out indicators of success for policy evaluation and implementation.

It is clear that the success of all planning, involving policy-makers and target groups, and connecting with relevant national, regional, continental and inter-continental organizations, is based on fundamental attitudinal assumptions, namely:

1. that the Portuguese language belongs to all who want to speak and/or use it;

2. that the Portuguese language has multiple identities and traditions and therefore, that its use, development and studies must always be contextualized and without prejudice to the languages and cultures with which it cohabits - translinguistic and transcultural postures are fundamental in this context.

\section{Phase Of The STATement OF NeEdS}

The identification and description of the historic-linguistic-cultural nature of the countries/societies leads to the specification of certain needs, such as the needs required by the recipients of the policy in terms of the development of the following:

1. proficiency in the four traditional linguistic-communicative skills, and also fluency; proficiency has to do with speech comprehension skills and writing processing skills - the exercise of proficiency is mostly practised through the acts of reading and writing, whereas fluency (Lopes, 2017; Lopes, 2018, p. 40) refers essentially to the prosody of language, to the pronunciation and timing of dialogue;

2. techniques that help in the comparison and contrast of the languages with which Portuguese coexists/ will coexist in both translinguistic and transcultural terms (Lopes, Mabasso \& Langa, 2016, pp. 42-49; Lopes, 2016, pp. 22-25). In this relationship of the study of language with the different types of culture, what is decisive is the intervention of the experienced teacher, the technician, the scholar and the expert on applied linguistic issues, and the intervention of the specialist translator;

3. attitudes that enable (and emphatically, children and young people) to live harmoniously and to benefit from the plurilingual and pluricultural societies with which they are in contact, or with which they will be, in a wider world. In schools, students should be able to develop a fifth linguisticcommunicative ability (Lopes, 2013a, p. 148; Lopes, 1997, p. 74) based on the understanding and acceptance of the Other and their culture. Different traditions, habits, values, customs and cultural practices cannot be used in school textbooks, simply as background and as a resource or expedient for acquiring only linguistic and communicative skills;

4. skills that help to formulate appropriate policies for language and didactic training need specialists with an educational background, mainly policy-makers and decision-makers, linguists with a specialization in applied linguistics, interpreters and translators, L1 (first language), L2 (second language) and FL (foreign language) university language teachers. Policy-makers identify and use relevant sciences (such as Applied Linguistics, Social Linguistics, Communication Sciences, Cultural Studies, Psycholinguistics, and other fields such as Economics, Demographic Geography, and Political Science) in a transdisciplinary manner, to clarify the nature of the problem (the situation) that it is intended to solve and to deduce possible solutions. When the policy-makers' experience and theoretical-practical knowledge of the situation (problem) is not adequate, the proposed policy and mode of implementation will be inappropriate. The policy-maker must lead us to question the management principles of decision-making, that is, to question the bureaucratic temptation to put eminent people, particular politicians, and executives as policy-makers and decision-makers instead of the qualified specialist, the relevant academic, etc.; and 
5. use of specific bilingual and multilingual training programmes, including the use of self-learning (using certain centres for this purpose), e-learning, distance learning based on certain digital platforms and tele-conferencing. As I have already mentioned (Lopes, 1997, p. 34), it is imperative to ensure the quality of any intervention, with realistic times of preparation and execution, conditions of implementation, use of appropriate methodologies, appropriate didactic materials... and much political will. The worst case scenario is to see impatient and unfit politicians, administrators or policy-makers formulating low-quality programmes which, to make matters worse, are often put into practice by incompetent technicians, producing feeble results, inadequate in terms of the skills and resources required by individuals and sectors from different societies.

\section{Alignment PHASE OF IndicAtors OF SUCCESS}

As for the expansion of Portuguese, is not it worth reconsidering its relative importance in global terms? Equating it in a more plurilingual and pluricultural way, according to the contexts in which it operates? These questions may perhaps, in an exploratory way, lead us to questions such as:

- how many Europeans and Americans speak Portuguese?;

- how many African and Asian Portuguese-speakers are expected to come to speak that language in 2050, as L2, FL and as L1, according to goals outlined?;

- how many Africans and Asians in the regions in which Portuguese-speaking countries are located currently have any knowledge of Portuguese? Is the number reasonable? And what predictions are there up to the year 2050?;

- what role does/will Portuguese play in their lives? Do they/will they enjoy the cultural resources that the language provides, or do they/will they simply use Portuguese essentially as a vehicular language?;

- what effects do/will economic globalization have on the demand for Portuguese in the CPLP?;

- does/will the evolution of regional blocs, such as SADC, occur in the sense of the promotion and diffusion of lingua francas that challenge the position of Portuguese in Mozambique or Angola?;

- how does/can Portuguese contribute to the economic modernization of a country like a more industrialized Mozambique?;

- is the expansion of Portuguese leading, or will it lead, to the extinction of several African or Asian languages in Africa or Asia?;

- is it that over the course of these years Portuguese has proved to be an important resource for each of the CPLP countries, providing them with economic advantages over other aggressive international competitors?;

- have you studied or are you considering starting to study literature in an African or Asian language, and do you foresee using existing literature from neighbouring countries that share the African or Asian language in question?

\section{Conclusion}

I conclude by emphasizing the importance of a transdisciplinary posture to research and the teaching-learning process. In transdisciplinary terms, different researchers, educators and learners work together transversally, through and beyond their issues, with a view to creating conceptual, theoretical, methodological and translational innovations that integrate and transcend specific approaches related to a single discipline to address 
a particular common problem. New spaces of knowledge are created, moving from the relations between disciplines, concepts and methodologies, in a proactive and retroactive way, in search of solutions to existing problems and which are felt in society.

It has been argued that there is not, nor there will not be a real Lusophony without sharing, without reciprocity, without interpenetration of the speech and cultures of the speakers and writers of the various languages that millions of CPLP citizens use both natively and non-natively. Portuguese will be powerful if it is sanctioned by many, if possible by almost all, if it is recognized as an important language, with its own dynamics for change and full of vitality, and if it is recognized as an important world language, if identification with language in which the speaker sees himself is also sanctioned by others, including those who grant the Portuguese language a co-citizenship status in their plurilingual and pluricultural contexts.

In the case of Mozambique (and other nations independent less than half a century ago), the colonial situation made cohabitation of Portuguese with indigenous languages and other implanted languages extremely difficult, resulting then in the hegemony of Portuguese and the devaluation of languages that at least ought to have accompanied it, to some extent, in its status and development. In this context, it is argued that Portuguese-language programmes should, as far as possible, incorporate language and culture practices that ensure a conscious protection of indigenous languages with which it coexists in plurilingual and pluricultural contexts. It will certainly be the starting point for an adequate language planning and language policy under construction for all the CPLP countries, and a possible passage to Lusophony, ideally.

Finally, the ecological system of Portuguese, which penetrates different states, regions and communities in the world, requires concerted planning and policies, including international linguistic-cultural relations that are relevant to specific contexts in Lusophony. For example, given Mozambique's privileged relationship with the People's Republic of China (as well as other states of the CPLP), and taking into account post-independence exchange experiences, as it happened with the specialized training in the Portuguese language of various Chinese citizens (some of them, nowadays, Ambassadors in various parts of the world) in Mozambique in the 1970s and 1980s, through the Faculty of Letters of the Eduardo Mondlane University (UEM), programmes for the spread of the Portuguese language in the SADC region could, for example, benefit from Chinese support, including from the Confucius Institute, which was established in 2012 in the UEM in Maputo for the diffusion of Chinese, and which runs short-term (four-month) courses from the outset, and undergraduate courses in Chinese language and culture attended by hundreds of students, since 2016. In the SADC Treaty, which brings together fifteen Southern African countries, the two official languages of the organization are English and Portuguese. But what is certain is that since 1992, the year of its foundation, the Community has taken very small steps in relation to the use of Portuguese in official, oral and written, communications. And we could continue with more considerations, such as, for example, the role of English in Mozambique, which is also a member of the Commonwealth. In a nutshell...many things available for reflection can also be considered 
through the disciplines of Language Planning and Language Policy, pillars of an Applied Linguistics, as we understand it in the contemporary world of linguistic-cultural diversity and globalization, an authentic crossing towards the intended Lusophony.

\section{Translation: Armando Jorge Lopes}

\section{REFERENCES}

Barson, T. \& Gorschlüter, P. (Eds.) (2010). Afro modern: journeys through the black Atlantic. London:Tate Publishing.

Craveirinha, J. (1954, 6 de novembro). Consciência da raça. O Brado Africano.

Deleuze, G. \& Guattari, F. (1980/2004). A thousand plateaus. Vol. 2 de Capitalism and Schizofrenia. London: Continuum.

James, C. (1993). What is applied linguistics? International Journal of Applied Linguistics 3(1), 17-32. DOI: $10.1111 / j .1473-4192.1993 . t b 00041 . x$

Kaplan, R. B. \& Baldauf, Jr., R. B. (1997). Language planning: from practice to theory. Sydney: Multilingual Matters.

Lopes, A. J. (1997a). Política linguística: princípios e problemas/Language policy: principles and problems. Maputo: Livraria Universitária.

Lopes, A. J. (1997b). Language policy in Mozambique: a taboo? In R.K. Herbert (Ed.), African linguistics at the crossroads: papers from Kwaluseni (pp. 485-500). Colonia: Rüdiger Köppe Verlag Köln.

Lopes, A. J. (1998). Introdução: universidade e investigação. In A. J. Lopes (Ed.), Universidade e investigação: comunicações de Maputo (pp. i-xii). Maputo: Livraria Universitária.

Lopes, A. J. (1999). The language situation in Mozambique. In R. B. Kaplan \& R. B. Baldauf, Jr. (Eds.), Language planning in Malawi, Mozambique and the Philip pines (pp. 86-132). Clevedon: Multilingual Matters.

Lopes, A. J. (2002). O Português como língua segunda em África: problemáticas de planificação e política linguística. In M. H. M. Mateus (Ed.), Uma política de língua para o Português (pp. 15-31). Lisboa: Edições Colibri.

Lopes, A. J. (2004). Língua, línguas: homogeneizar, heterogeneizar? PROLER, 12, 32-34.

Lopes, A. J. (2012, 23 de agosto). A minha concepção a respeito da lusofonia. Ndhaneta [blog]. Retrieved from http://ndhaneta.blogspot.com/2012/08/ideias-minha-concepcao-respeito-da.html

Lopes, A. J. (2013a). Língua portuguesa em Moçambique: timakas, milandos e desafios. Revista Brasileira, 74, $117-134$.

Lopes, A.J. (2013b). Criando a região inteligente: o caso do português na comunidade do desenvolvimento da África Austral (SADC). Platô - Revista do Instituto Internacional da Língua Portuguesa, 4(2), 28-41.

Lopes, A. J. (2015). Política linguística: terra de ninguém, terra de todos: notas a partir de um posto de observação moçambicano. In M. L. Martins (Ed.), Lusofonia e interculturalidade - promessa e travessia (pp. 197-226). Vila Nova de Famalicão: Húmus. Retrieved from http://www.lasics.uminho.pt/ojs/index. php/cecs_ebooks/article/view/2202 
Lopes, A. J. (2016). Comunicação translinguística e transcultural com enfoque na linguagem idiomática: uma análise contrastiva discursiva entre o Português, Xichangana e Inglês. Todas as Letras, 18(1), 22-36. Retrieved from http://editorarevistas.mackenzie.br/index.php/tl/article/view/8870/5631

Lopes, A. J. (2017). Cutucando a onça com vara longa: da transdiscursividade à transculturalidade na lusofonia. Opening conference (keynote address) of the $7^{\circ}$ Seminário Internacional de Linguística/III Congresso Interdisciplinar de Cortesia/II Simpósio de Linguística Textual: Discurso e Interdisciplinaridade. Campus Anália Franco, Unicsul, São Paulo.

Lopes, A. J. (2018). O aluno universitário moçambicano PL2 e os caminhos da escrita: Um trilho seguro vale mais do que os dois que puseram a quizumba a mancar. Revista Linha d'Água, 31(1), 29-49. DOI: $10.11606 /$ issn.2236-4242.v31i1p29-49

Lopes, A. J., Mabasso, E. \& Langa, P. (2016). Com Todos os efes e erres: para um léxico de usos idiomáticos - Português-Inglês-Xichangana/With all the bells and whistles: towards a lexicon of idiomatic usage Portuguese-English-Shangaan/Kudlaya Nsuna ni Bawa: Ta Kukongoma marito Ya Kufambelana ni Kutirhisa Svivulavulelo-Xiputukezi-Xinghiza-Xichangani. Maputo: Livraria Universitária.

Macedo, L. (2013). Da diversidade do mundo ao mundo diverso da lusofonia: a reinvenção de uma comunidade geocultural na sociedade em rede. Doctoral thesis in Communication Sciences, University of Minho, Braga, Portugal. Retrieved from http://hdl.handle.net/1822/28851

Martins, M. de L. (2012, 23 de agosto). Comentário ao apontamento de A. J. Lopes, 'A minha concepção a respeito da Lusofonia', publicado em Ndhaneta em 2012. 'Caderno Cultural' do Diário Notícias.

Martins, M. L. (2014). Língua portuguesa, globalização e lusofonia. In N. Bastos (Ed.), Língua portuguesa e lusofonia (pp. 15-33). São Paulo: Educ, IP-PUC. Retrieved from https://repositorium.sdum.uminho.pt/ handle/1822/29178

Mosquera, G. (2001). Notes on globalisation, art and cultural difference. RAIN Artists'Initiatives Network. Rijksakade-mie van beeldende kunsten, Amsterdam.

Ortiz, F. (1940/1963). Contrapunteo Cubano del Tabaco y el Azúcar. Advertencia de sus Contrastes Agrarios, Económicos, Históricos y Sociales, su Etnografia y su Transculturación. Havana: Consejo Nacional de Cultura.

Osgood, C. E. (1949). The similarity paradox in human learning: a resolution. Psychology Review, 56, $132-143$. DOI: $10.1037 /$ hoo 57488

Pratt, M. L. (2005) Transculturação e autoetnografia: Peru 1615/1980. In M. R. Sanches (Ed.), Deslocalizar a Europa (pp. 231-259). Lisboa: Edições Cotovia.

Rajagopalan, K. (2003). Por uma linguística crítica: linguagem, identidade e a questão ética. São Paulo: Parábola.

Robinson, C. D. (1993). Where linguistic minorities are in the majority: language dynamics amidst high linguistic diversity. AILA Review,10, 52-70.

\section{BIOGRAPHICAL NOTE}

Armando Jorge Lopes, who holds an MA (York, UK, 1982), a PhD (Wales, UK, 1986) \& post-doctorates (USC, California, 1991 \& Cambridge, UK, 1993), is an applied linguist and has been involved in language teaching for more than 45 years - as a private tutor for English (1967), a high school teacher (1972-1977), University lecturer, researcher and 
manager (1977--) and Full Professor (2000--) at the Eduardo Mondlane University in Mozambique. He has taught doctoral and post-doctoral programmes also at universities in Europe, America and other countries in Africa. At the UEM, he has served as Pro-ViceChancellor for Pedagogic Affairs (1987-90), Deputy Dean of the Arts Faculty for Research (1993-1996), Head of the Linguistics \& Literature Department (2001-2004), and Dean of the Faculty of Arts and Social Science (2007-2012). He was the Deputy Vice-Chancellor (Academic) of the Polytechnic University in Mozambique (2015-2017). In Southern Africa he was appointed Editor-in-Chief of LASU, the Linguistics Association for public Universities in SADC's 15 countries (1990-1995), and has carried out simultaneous interpretation and translation tasks at SADCC and other political and economic institutions in Mozambique and elsewhere (1975-1994). Has published 12 books and about a hundred refereed articles in international and national periodicals.

ORCID: https://orcid.org/0000-0001-9395-8987

Email: ajplopes@zebra.uem.mz

Address: Universidade Eduardo Mondlane, Campus Universitário Principal, Av. Julius Nyerere, nr. 3453 Maputo, Moçambique

* Submitted: 14.05 .2018

* Accepted: 13.06.2018 